${ }^{\circ}$ Entomologica Fennica. 29.VI. 1990

\title{
Revision of the Atomophora complex (Heteroptera, Miridae) of the Eremian subregion
}

\author{
Rauno E. Linnavuori
}

Linnavuori, R. E. 1990: Revision of the Atomophora complex (Heteroptera, Miridae) of the Eremian subregion. - Entomol. Fennica 1:45-64.

The Atomophora Reuter genus complex of North Africa and the Middle and Near East is revised. New synonymy: Taeniophorus grandoculus Linnavuori = Camptotylidea astarte (Linnavuori). New combinations: Atomophora alba Reuter, A. albovittata Reuter, A. alhagii Linnavuori, A. astarte Linnavuori, A. astragalii Linnavuori, A. bipunctata Reuter, A. bast Linnavuori, A. candida Linnavuori, A.flavescens Puchkov, A. fuscomaculata Reuter, A. lineata Reuter, A. modesta Linnavuori, A. pallescens Puchkov, A. suturalis Reuter, and A. vitticollis Reuter are transferred to the genus Camptotylidea Wagner. A neotype is designated for Atomophora macrophthalma Poppius and lectotypes for Atomophora maculosa Reuter, A. oculata Reuter, A. pantherina Reuter, Camptotylidea alba (Reuter), C. albovittata (Reuter), C. lineata (Reuter) and C. suturalis (Reuter).

Rauno E. Linnavuori, Somersoja, SF-21220 Raisio, Finland

Reuter (1879) described the genus Atomophora for a group of phyline species with a maculate pattern, simple hair covering, maculate tibiae, and a special claw structure. Wagner (1973:406-410) defined the genus mainly on the basis of the claw structure: claws (Fig. 3j) short, provided with nearly semicircular pulvilli arising from basal tooth of claw and directed ventrad. He regarded this as sufficient to establish a distinct group, the Atomophoraria, for the genus. I have pointed out (Linnavuori 1984:40 and 1986:154-155) that Atomophora also includes numerous species with long, slender claws and elongate pulvilli (Fig. 4d). After revising the known species, I am convinced that the old genus Atomophora consists of two monophyletic groups, which differ from each other in the claw structure. The general coloration of species in these two groups also differs, although one species (A. subpallida) of the first group is unusually pale and certain species of the second group have maculate tibiae and major infuscations on the upper surface. The first group is Atomophora Reuter. Wagner (1957:92-93) described the monotypic genus Camptotylidea from Iran. He correctly pointed out that Camptotylidea has affinities with the genera Megalocoleus Reuter and Solenoxyphus Reuter, but he did not realize its close relationship to Atomophora. The genus has not been treated since. A recent survey of some of Wagner's mirid types revealed that the type of the genus, $C$. persica, is very similar to several species which were formerly included in Atomophora. Hence, these species are transferred to Camptotylidea. A further genus of the complex is Taeniophorus, which was described by me in 1952. The only known species, $T$. hyalinus Linnavuori, is unusually pale and long-headed, but otherwise it displays the basic characters of the group, including the dark dotting on the elytra, which is seen in some specimens. Taeniphorus is an undoubted derivative of the Camptotylidea stock. 
The claw structure of Atomophora is obviously an advanced character, which is apparently somehow connected with the life on Calligonum, but since it is otherwise closely related to Camptotylidea, Wagner's establishment of the group Atomophoraria is not justified. The Atomophora complex belongs, in fact, to the Phylus group (see Wagner, 1975), resembling the genera Solenoxyphus Reuter and Malthacosoma Reuter in the maculate pattern, but being distinguished trom these by the small size, coloring, shape of the head, pale hair covering, short and pale tibial spines, and the prominent pulvilli.

Diagnosis of the Atomophora complex: small pale ochraceous or greenish species with maculate pattern on upper surface. Tibiae usually with distinct dark spots. Hair covering on upper surface simple, pale. Head short and broad, in apical view broader than high with lower part below eyes very short. Tibial spines short and pale. Pulvilli prominent. Vesica slender, simple.

Key to the genera of the Atomophora complex

1. Claws (Fig. 3j) with nearly semicircular pulvilli arising from basal tooth and directed ventrad .... Atomophora

- Claws with long pulvilli

2. Head in lateral view distinctly longer than high. Hind tarsus (Fig. $6 \mathrm{r}-\mathrm{s}$ ) short and incrassate, apex of 2 nd joint bluntly oblique, pulvilli very broad and extending to near apex of claw Taeniophorus

- Head in lateral view higher than long. Hind tarsus (Fig. $6 \mathrm{i}-\mathrm{j}$ ) gracile, apex of 2 nd joint sharply triangular, pulvilli smaller. Camptotylidea

\section{Genus Atomophora Reuter}

\section{Atomophora Reuter 1879:187.}

Type species: A. pantherina Reuter.

Diagnosis: Maculate pattern usually well developed. Claws short, strongly broadening basad: pulvilli nearly semicircular, arising from basal tooth of claw and directed ventrad.

Color: Ground color pale ochraceous. Upper surface with abundant fuscous markings, as seen in Fig. 1a-c, f. Antennae pale, 1st joint with dark or reddish subapical spots or totally brown. Pronotum with \pm confluent dark brown or reddish spots and irroration. Elytra with fuscous, often confluent spots, pale areas with numerous dark or reddish dots, medioapical angle of corium with large dark spot; membrane whitish with abundant brown irroration. Under surface brown. Femora pale with dark spots or, hind femora especially, dark brown. Tibiae usually with distinct, rarely faint, dark spots.

Body small, length $<5 \mathrm{~mm}$, elongately ovate. Hair covering on upper surface simple, dense, semidecumbent and pale. Head short and broad, in apical view broader than high with lower part below eyes very short, in lateral view higher than long, frons moderately convex, separated by shallow depression from the prominent tylus; eyes large, in male voluminous, extending to ventral margin of head or nearly so. Antennal pits below middle of median margins of eyes; antennae long, 2nd joint in $\sigma^{7} \pm$ incrassate, hair covering of antennae short, \pm adpressed. Rostrum extending to middle or hind coxae. Pronotum short, trapazoidal, lateral margins straight. Prosternal xyphus shallowly concave. Tibial spines pale. 3rd joint of hind tarsus as long as or longer than 2nd, apex of 2nd joint sharply triangular, as in Fig. 6j. Claws (Fig. 3j) short, strongly broadening basad, pulvilli nearly semicircular, arising from basal tooth of claw and directed ventrad.

Male genitalia of the common phyline type. Vesica arcuate, ending in a falcate apical portion.

Biology: On Calligonum.

Distribution: Eremian.

Key to the species of Atomophora

1. Femora (Fig. 1c) pale, ornamented with dark spots ..2

- Femora dark brown, basally pale .............................. 4

2. Body gracile, about $3 \times$ as long as broad. Antennae remarkably slender, 2 nd joint in $\sigma^{7} 1.51 \times$ as long as diatone, Upper surface with dense \pm confluent dark brown spots .................................................... eximia

— Body robuster. Antennae thicker, 2nd joint considerably shorter.

3. Entire upper surface, including cuneus, with abundant fuscous mottling. Scutellum with $\mathrm{X}$-shaped fuscous figure extending from base on to apical part. 2nd antennal joint $1.30-1.35 \times$ as long as diatone maculosa

- Upper surface paler. Apex of scutellum immaculate, pale yellow; cuneus pale, immaculate or with very faint scanty orangish dots. 2 nd antennal joint $1.05-1.09 \times$ as long as diatone ............................................... oculata 
4. Cuneus dark brown with basal margin and apex whitish. 1 st antennal joint dark brown ................................ 5

- Cuneus pale, ornamented with faint orangish or pink irroration. 1st antennal joint pale with reddish ring . 6

5. Body narrow, parallel-sided, about $3 \times$ as long as broad. Elytra with very large, confluent dark brown spots; cuneus apically and basally broadly pale.. pantherina

- Body broader, ovate, about $2.5 \times$ as long as broad. Elytra with smaller and relatively few confluent dark brown spots; only extreme tip of cuneus pale ....... nut

6. Pronotum dark brown with a contrasting pale median stripe (Fig. 1f). Base of scutellum dark brown, apex uniformly whitish ..... pentheus

- Pronotum pale ochraceous with \pm abundant fuscous irroration. Apical part of scutellum with brown irroration... 7

7. Eyes in $\sigma^{7}$ very large; ocular index $0.30-0.98\left(\sigma^{7}\right), 1.8$ (o). Tibiae with conspicuous dark spots macrophthalma

- Eyes smaller; ocular index 1.11-1.33 ( $\left.0^{7}\right)$, about 2.05 (o). Tibiae with small dark spots arabica

A. subpallida Wagner and $A$. basipunctata Wagner, not examined by me, are excluded from the key: since their descriptions might be interpreted in slightly different ways, they are grouped in their original language after the species included in the key.

\section{A. eximia Reuter}

Atomophora eximia Reuter 1879:288.

Material studied: USSR: Peski Mujun-Kum ob., Kargaly-kul, 10', 28.V.1910, Kiritshenko, in coll. Linnavuori.

Diagnosis: Body gracile, $3 \times$ as long as broad. Dark pattern abundant. Femora pale with dark spots. Antennae long, 2nd joint $\left(0^{7}\right) 1.5 \times$ as long as diatone.

Length $4 \mathrm{~mm}$. Head reddish brown; eyes dark gray. Antennae yellowish brown, 1st joint reddish brown with two dark setigerous subapical dots. Calli dark brown, rest of pronotum whitish ochraceous with dense confluent dark brown mottling. Scutellum reddish brown with minute faint pale areas. Clavus, corium and cuneus whitish gray with numerous \pm confluent large dark fuscous spots, pale interspaces with dense dark brown dotting; membrane brownish smoky with pale irroration, veins reddish, partially pale. Under surface dark reddish brown. Femora golden brown with dark brown spots. Other parts of legs pale ochraceous, tibiae with distinct dark brown spots, tibial setae brownish.
Body gracile, about $3 \times$ as long as broad. Ocular index $\left(\sigma^{\top}\right)$ 1.15. Antennae long and gracile, proportions between joints 15:70:48:23, 2nd joint $1.51 \times$ as long as diatone.

Distribution: Turkestan.

Close to A. maculosa, but distinguished by the gracile body, more intense dark pattern and much longer and more gracile antennae.

\section{A. maculosa Reuter}

Fig. 1e

Atomophora maculosa Reuter 1904:12.

Types studied: USSR, Aschabad, female syntype, designated here as the lectotype, 1 syntype (fragmentary, only one elytron and leg left) Ahnger, in Mus. Helsinki.

Material studied: USSR: Transcaspia, Utsh-Adzhi, 5 exx, 8.IV.1900, Germs, in coll. Linnavuori.

Diagnosis: Like A eximia, but body robuster, $2.5 \times$ as long as broad. 2 nd antennal joint about 1.3 $\times$ as long as diatone. Length of body $4.0-4.25 \mathrm{~mm}$. Apex of vesica long and gracile.

Length $4.0-4.25 \mathrm{~mm}$. Coloring as in the following subspecies.

Body about $2.6\left(\sigma^{7}\right)$ or $2.5(\%) \times$ as long as broad at middle of elytra. Ocular index 1.15-1.24 $\left(\sigma^{\top}\right), 1.51-1.83$ (O). Proportions between antennal

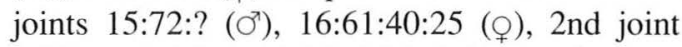
$1.25-1.45\left(\mathrm{O}^{7}\right)$ or $1.31-1.35($ (६) $\times$ as long as diatone.

Male genitalia: Apex of vesica (Fig. 1e) long and gracile, tip acute.

Biology: On Calligonum densum and C. caput-medusae (Puchkov 1975:947).

Distribution: Turkestan.

\section{A. maculosa erato Linnavuori}

Fig. 1c-d

Atomophora maculosa erato Linnavuori 1971:8.

Types studied: Iran, Baluchistan, Iranshar, $800 \mathrm{~m}$, female holotype and 2 paratypes, 28-31.III. 1954, Richter \& Schäuffele, in coll. Linnavuori, 2 paratypes from the same locality in Mus. Stuttgart.

Diagnosis: Smaller than the nominate form, length $3.5 \mathrm{~mm}$. Apex of vesica shorter and thicker, tip finely crenulate. 
Lenghth $3.5 \mathrm{~mm}$. Pale gray or grayish ochraceous. Upper surface with dense pattern of dark brown or red spots. Head with intense brown and red markings, the pale ground color visible only medially and basally, eyes dark gray. Antennae yellow-brown, 1st joint with reddish subapical ring. Pronotum with dense \pm confluent dark brown and reddish spots and irroration. Scutellum with $\mathrm{X}$-shaped fuscous figure extending from base on to apical part. Elytra, including cuneus, with evenly distributed, \pm confluent fuscous spots, inner basal angle of corium with largish dark spot, pale areas of elytra with small brown dots; membrane smoky with faint pale irroration, veins whitish or partially reddish. Under surface yellow-brown with fuscous or sanguineous markings. Legs pale yellow-brown, fore and middle femora with a row of fuscous or red spots on ventral margin, hind femora in apical half densely spotted with brown or red; tibiae with distinct dark spots, spines pale.

Like the nominate form, but much smaller. Ocular index 1.21 ( $\left.\sigma^{7}\right)$, 1.9-2.1 (Q) ). Proportions between antennal joints 5:25:11:? ( $\left.\bigcirc^{7}\right), 4: 22: 15: 9$ (Q), 2nd joint $1.4\left(\bigcirc^{\top}\right)$ or $1.22-1.26(\%) \times$ as long as diatone.

Male genitalia: Apex of vesica (Fig. 1d) shorter and thicker, extreme tip finely crenulate.

Distribution: Iran.

\section{A. oculata Reuter}

Figs. 2, 3p

Atomophora oculata Reuter 1904:10

Types studied: USSR, Aschabad, male syntype, designated here as the lectotype, 1 syntype (fragmentary, only remnants of legs left), Ahnger, in Mus. Helsinki.

Material studied: USSR: Peski Koilibai M. Basrsuki, Turg., 1 ex, 12.VI.1931, Luppova; Transcaspia, Repetek, 1 ex, 4.V.1909, A. Hohlbeck; Transcaspia, Karaul-Kuju, 1 ex, 14.V.1914, in coll. Linnavuori.

Diagnosis: Like A. maculosa but paler, cuneus and apex of scutellum pale, nearly immaculate. Eyes in $\sigma^{7}$ very large, broader than vertex.

Length $3.25-3.5 \mathrm{~mm}$. Coloring as in A. maculosa, but apical part of scutellum contrastingly whitish ochraceous, immaculate or with a few very faint orangish dots. Fuscous pattern on elytra more scanty, basal quarter of elytra pale with a few very small orangish or brownish dots; cuneus pale with a few faint reddish dots.
Eyes in $\sigma^{7}$ very large, ocular index $0.89-0.91$ (ऽ), 1.7 (o). 2 nd antennal joint $1.05-1.09 \times$ as long as diatone.

Male genitalia: Vesica in Fig. 3p.

Biology: On Calligonum arborescens, C. densum and C. setosum (Puchkov 1975:947).

Distribution: Turkestan.

\section{A. pentheus Linnavuori}

Figs. 1f, 4a

Atomophora pentheus Linnavuori 1971:4-6.

Types studied: Iran, Baluchistan, Iranshar, $800 \mathrm{~m}$, male holotype and 2 paratypes in coll. Linnavuori, 4 paratypes in Mus. Stuttgart, 11-18.III.1954, Richter \& Schäuffele; Djiroft, Anbar-Abad, 1 paratype, 21-30.IV.1956, Richter, in Mus. Stuttgart.

Diagnosis: Upper surface with abundant dark pattern. Pronotum dark brown with pale median stripe. Apex of cuneus uniformly whitish. 1st antennal joint pale with reddish ring. Femora dark brown, basally pale.

Lenghth 3.0-3.2 mm. Head dark brown, with irregular contrasting pale median stripe extending from tylus to base of vertex; the dark sides sometimes traversed by pale arcs, in one specimen entire head whitish yellow. Eyes dark brown. Antennae yellow-brown, with orangish tinge, 1st joint dark reddish, apex and base pale. Pronotum dark brown, with a constrasting whitish yellow median line, the dark areas sometimes with pale irroration, in one specimen lateral margins of pronotum also pale. Base of scutellum dark brown, apex contrastingly whitish yellow. Elytra whitish, with \pm dense brown dotting and a few major brown spots, inner apical area of corium with large dark brown spot cuneus pale with orangish or pink irroration; membrane brownish smoky with pale irroration, veins orangish or whitish. Under surface purplish or dark brown. Fore and middle femora yellow-brown, apices with orangish tinge, hind femora dark brown. Legs otherwise whitish yellow, tibiae with dark dots, spines pale.

Body about $2.7 \times$ as long as broad. Ocular

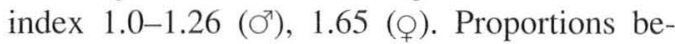
tween antennal joints 4:20:14:10 $\left(\sigma^{7}\right), 5: 20: 12: 9$ (O), 2nd joint $1.11\left(\mathrm{O}^{7}\right)$ or $1.13(\%) \times$ as long as diatone.

Male genitalia: Vesica in Fig. 4a.

Distribution: Iran. 


\section{A. arabica Linnavuori}

Fig. $3 g-\mathrm{O}$

Atomophora arabica Linnavuori 1962:69-70, 1986:158.

Type studied: Saudi Arabia, El Riyadh, male holotype, 5-19.IV.1959, Diehl, in coll. Linnavuori.

Material studied: Numerous exx from Iraq: Diyala, Wadi Mandali, 29.IX.1979; Salah ad Din, Tharthar lake, 13.IX.1979; Karbala, Ukhaydir-Nukhayb, 2.V.1980; An Najaf, Najaf-Shabakah, 23.VI.1981; Dhi Qar, $50 \mathrm{~km}$ SE of Nasiriyah, 14.IV.1980; Al Basrah, near Safwan, 13.IV. 1980, Linnavuori. Saudi Arabia: Jubbah, 20-21.XI.1977; Hamatiyat, 27.IV.1978; Al Hasa, X.1977; Hufuf, 23.IV-13.V.1978; An Nu'ayriyah, 26.IV.1978; As Sirar, 28.IV.1978; $50 \mathrm{~km} \mathrm{~N}$ of Urayrah, 12.IV.1978, Linnavuori, in coll. Linnavuori.

Diagnosis: Like A. pentheus, but pronotum pale ochraceous with fuscous irroration. Apex of scutellum irrorated with brown. Tibiae with small dark spots. Eyes small, ocular index 1.11-1.33 $\left(\sigma^{7}\right), 2.05(0)$.

Length $2.70-3.25 \mathrm{~mm}$. Ground color pale grayish ochraceous with dilute chocolate fuscous irrorations. Head with fuscous and sanguineous irroration, save in median line and basal margin, the latter with 4 sanguineous spots; eyes dark brown. Antennae pale yellowish, 1st joint with sanguineous subapical ring, joints 3 and 4 slightly infuscate. Anterior two-thirds and sides of pronotum with dense fuscous irroration, basal angles and middle of basal part sparsely irrorate, pale median line obscure. Scutellum with minute reddish brown irroration. Elytra with dense red and fuscous irroration, inner basal angle of corium with a major irregular dark fuscous spot, cuneus pale with faint orangish irroration; membrane smoky with whitish mottling. Under surface with conspicuous sanguineous markings. Legs pale yellowish ochraceous, hind femora fuscous, tibiae (Fig. 3i) with small inconspicuous dark dots.

Body $2.7 \times$ as long as broad. Eyes relatively small, ocular index 1.11-1.33 ( $\left(^{7}\right)$, about 2.05 in o. Antennae (Fig. 3h) slender, proportions between joints 12:52:35:20 (o ), 12:51:31:20 (Q), 2 nd joint $1.11-1.18 \times$ as long as diatone.

Male genitalia in Fig. 3k-0.

Biology: In Iraq found on Calligonum comosum. In Saudi Arabia common at lamps in Rhanterium epapposum steppes.

Distribution: Known from Iraq and Saudi Arabia.

\section{A. macrophthalma Poppius}

Fig. 3a-f

Atomophoramacrophthalma Poppius 1909:234, Linnavuori 1986:157.

Types studied: As pointed out in Linnavuori (1971:4), the holotype of macrophthalmus has undoubtedly been lost. To fix the nomenclature a male from Saudi Arabia, Layla, 30.VI.1978, Linnavuori, in coll. Linnavuori is here designated as the neotype.

Material studied: Saudi Arabia: $240 \mathrm{~km} \mathrm{~S}$ of Dawasir, 1 ex, 4-5.II.1978; Najran, 1 ex, 6-10.II.1978; Najran-As Sharawrah, 2 exx, 8-9.II.1978; Al Ayun, 1 ex, 18.VI.1978; Al Uqayr, 1 ex, 12.V.1978, Linnavuori, in coll. Linnavuori.

Diagnosis: Like A. arabica, but tibiae with large dark spots. Eyes larger, ocular index $<1.0$ $\left(0^{7}\right),<2.6(Q)$.

Like the preceding species, but eyes much larger, especially in $\sigma^{7}$, ocular index $0.80-0.98$ $\left(0^{7}\right), 1.8(0)$, body somewhat shorter and broader, 2nd antennal segment shorter and broader (proportions between joints 12:54:35:22 ( $\left.\sigma^{7}\right), 2$ nd joint $0.90-1.19 \times$ as long as diatone), and tibiae with conspicuous dark spots.

Male genitalia as in the preceding species. Vesica in Fig. 3e-f.

Distribution: Originally described from Bou Harmes in the Sahara.

\section{A. nut Linnavuori}

Figs. 1b, 2a-b, 4b

Atomophora nut Linnavuori 1971:7-8.

Types studied: Algeria, Ain Sefra, male holotype and 3 paratypes, 5-6.V.1964, Eckerlein, in coll. Linnavuori; Iran, Baluchistan, Iranshar, 800 m, 2 paratypes, 11-18.III.1954, Richter \& Schäuffele, in Mus. Stuttgart.

Material studied: Israel: Timna, I ex, 27.III.1987, Carapezza, in coll. Carapezza. Saudi Arabia: Abqaiq, several exx, 9.III.1978; near Abu Hadriyah, 2 exx, 26.I.1978; $75 \mathrm{~km}$ E of Zarqani, 1 ex, 24.III.1978, Linnavuori, in coll. Linnavuori.

Diagnosis: Like A. pantherina, but body broader, $2.5 \times$ as long as broad. Dark spots on elytra smaller, only extreme tip of cuneus pale.

Length 3.5-3.75 mm. Head, pronotum and scutellum blackish or dark brown. Head with irregular pale ochraceous or reddish midline, broadest at base of vertex; eyes brown. Antennae yellow-brown, 1st joint dark brown or blackish, base 

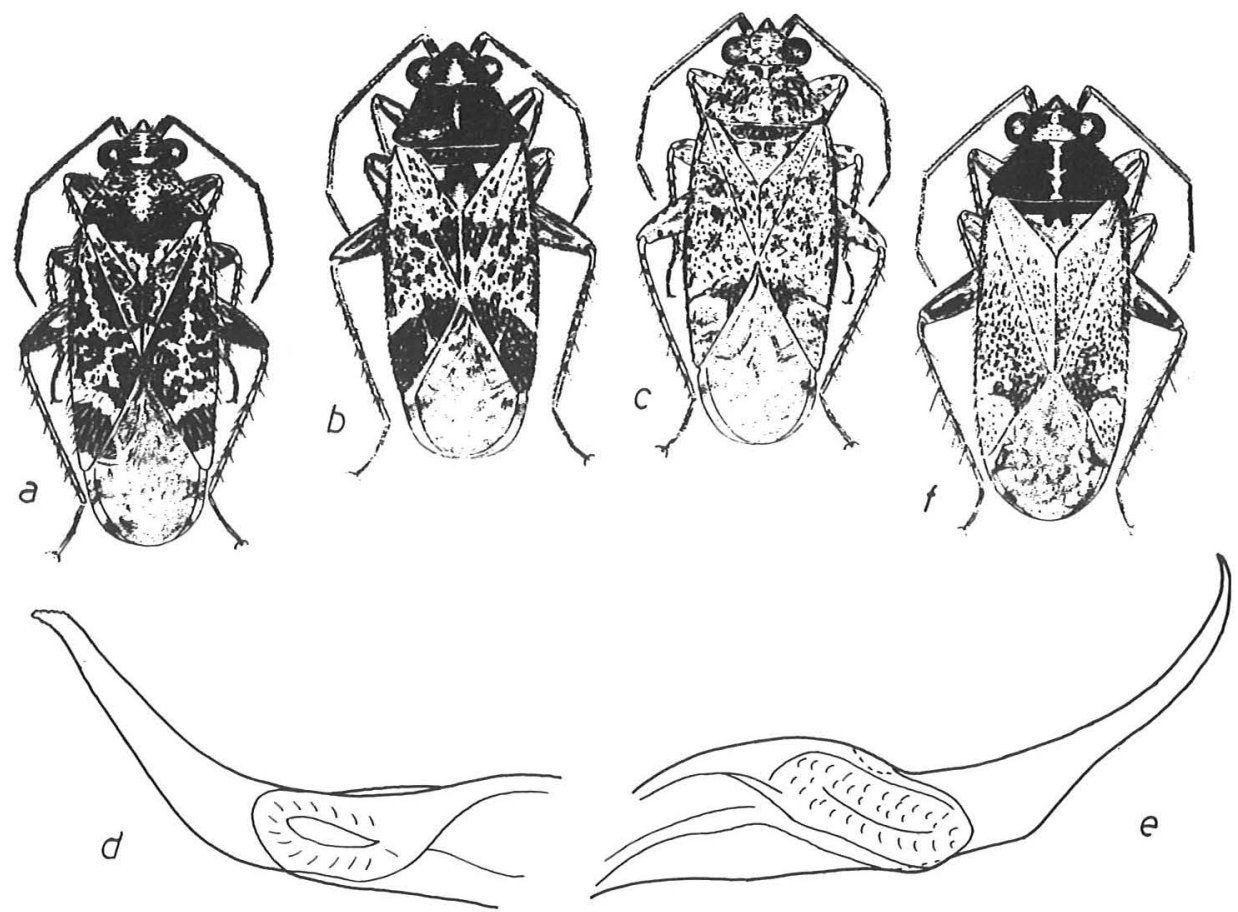

Fig. 1. Atomophora pantherina Reuter. a: dorsal view. - A. nut Linnavuori. b: dorsal view. - A. maculosa erato Linnavuori. c: dorsal view; d: apex of vesica. - A. maculosa maculosa Reuter. e: apex of vesica. - A. pentheus Linnavuori. f: dorsal view. $-\mathrm{a}-\mathrm{c}$ and $\mathrm{f}$ after Linnavuori 1971.
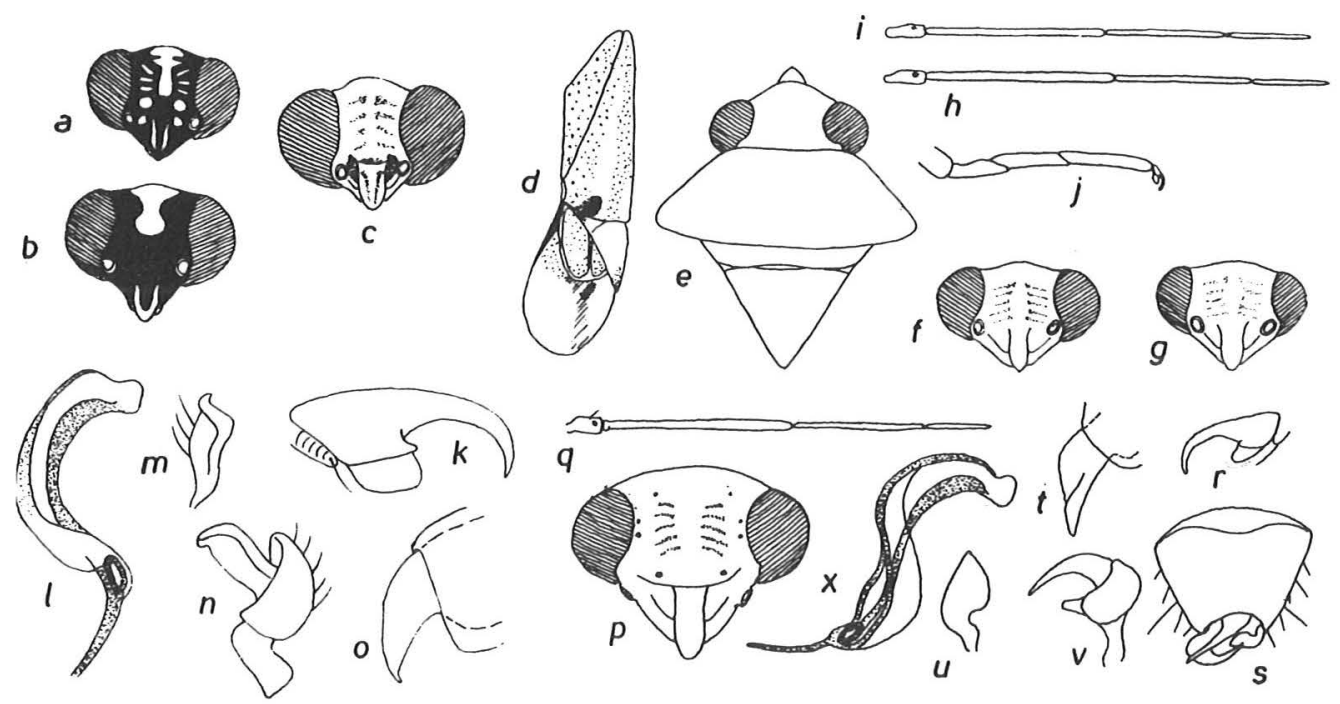

Fig. 2. Atomophora nut Linnavuori: a-b: male and female head in apical view. - A. oculata Reuter. c: male head in apical view. $-A$. subpallida Wagner. d: elytron; e: male head and thorax, dorsal view; $f-g$ : male and female head in apical view; h-i: male and female antenna; j: hind tarsus; $k$ : claw; l: vesica; $m$ : right style; $n$ : left style; o: theca. - A. basipunctata Wagner. p: male head in apical view; q: antenna; $r$ : claw; s: male genital segment, dorsal view; t: theca; u: right style; v: left style; x: vesica. — After Wagner 1970, 1973 and 1974. 

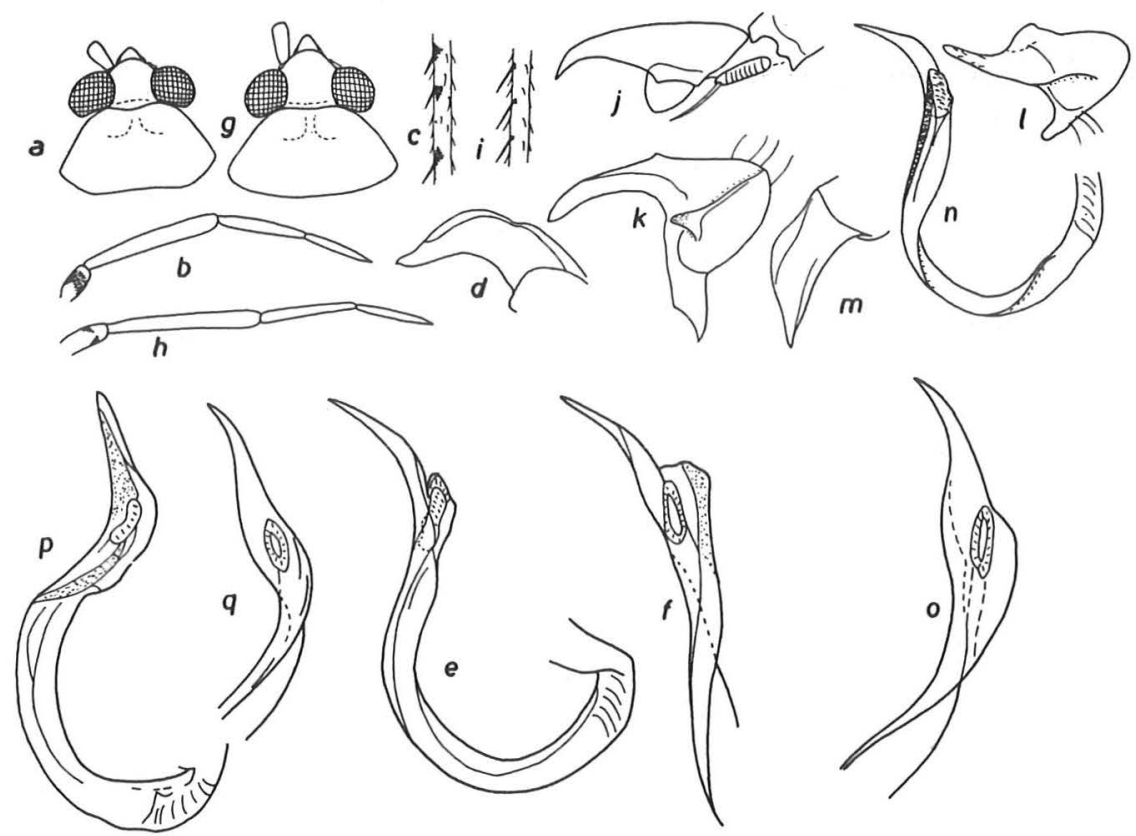

Fig. 3. Atomophora macrophthalma Poppius. a: male head and pronotum, dorsal view; $b$ : male antenna; c: pattern of hind tibia; $\mathrm{e}-\mathrm{f}$ : vesica. - A. arabica Linnavuori. g: male head and pronotum, dorsal view; $\mathrm{h}$ : male antenna; i: pattern of hind tibia; j: claw; k-l: left style; m: theca; n-o: vesica. —A. oculata Reuter; $\mathrm{p}$ : vesica.—After Linnavuori 1986.

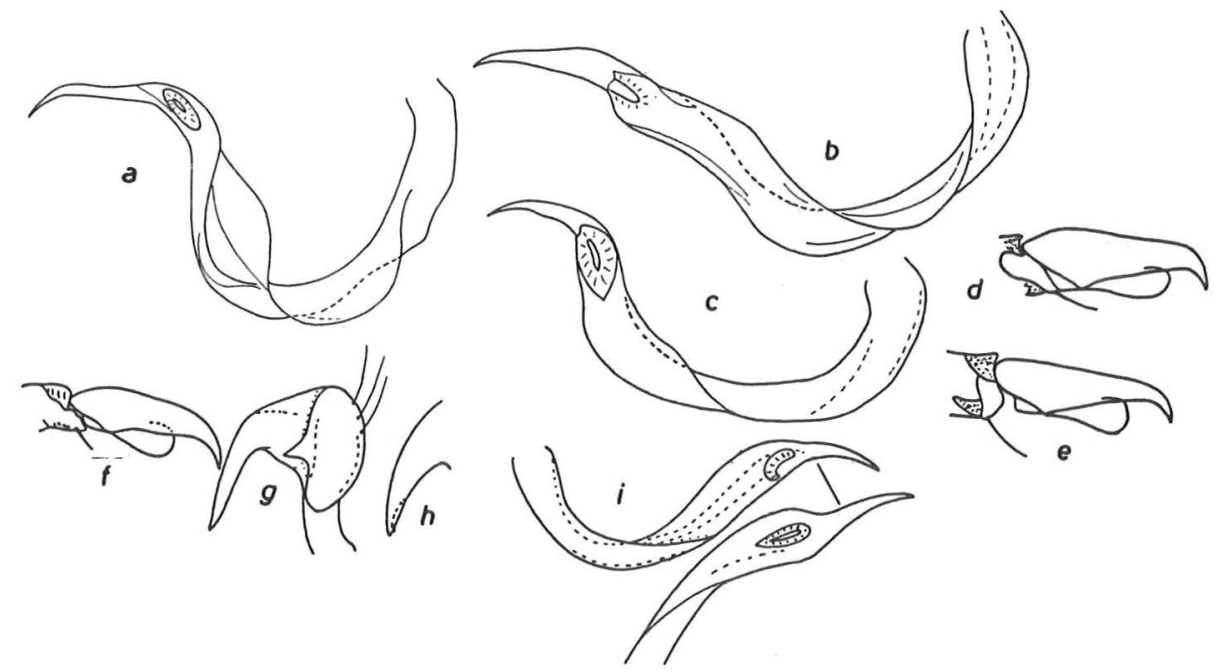

Fig. 4. Atomophora pentheus Linnavuori. a: vesica. - A. nut Linnavuori. b: vesica. - A. pantherina Reuter. c: vesica. - Camptotylidea alhagii (Linnavuori). d: claw. - C. suturalis (Reuter). e: claw. - C. candida (Linnavuori). f: claw: g: left style; h: theca; i: vesica. - After Linnavuori 1971, 1984 and 1986. 
of 2 nd joint also darkened. The pronotum is ornamented by a pale midline which may be very narrow and indistinct or \pm enlarged in middle. Apical part of scutellum with tip and two lateral basal spots yellow-brown. Elytra pale grayish ochraceous or whitish gray, cuneus (save extreme tip) and inner basal angle of corium dark brown, rest of corium and clavus with smaller and larger \pm confluent dark brown spots, the dark pattern most intense in apical two-thirds of corium, base relatively pale with only scanty dark markings; membrane brownish smoky with pale irroration, lateral margin with two major pale spots, veins pale. Under surface dark brown. Legs yellowbrown, hind femora dark brown, other femora also \pm darkened apically; tibiae with distinct dark spots, tarsi infumed.

Body robust, ovate, $2.3-2.6 \times$ as long as broad. Ocular index $1.17\left(0^{7}\right), 1.78(\varnothing)$. Antennae in $\sigma^{7}$ relatively incrassate, in $\odot$ gracile, proportions

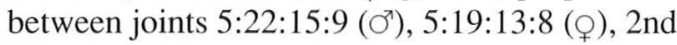
joint about $0.8 \times$ as long as basal width of pronotum.

Male genitalia: Vesica (Fig. 4b) thicker and more strongly curved than in the following species.

Biology: On Calligonum comosum.

Distribution: Eremian (Algeria-Iran).

\section{A. pantherina Reuter}

Fig. 1a

Atomophora pantherina Reuter 1879:289, Linnavuori 1971:229.

Type studied: USSR, Kizil-kum, male syntype, designated here as the lectotype, in Mus Helsinki.

Material studied: USSR: Buchara, Sands near the Mount Saman Dengis kul, 1 ex, 7.V.1911, A. Holbeck; Imam-baba, Merv. u Zakasts. 1 ex, Kožančikov; Repetek, Turcmenia, 1 ex, 31.V.1962, Trjapitzin, in coll. Linnavuori.

Diagnosis: With abundant dark pattern. 1st antennal joint dark brown. Elytra with large and confluent dark spots, apex and base of cuneus broadly pale. Femora dark brown, basally pale. Body $3 \times$ as long as broad.

Length $3.0-3.25 \mathrm{~mm}$. Like the preceding species but body much narrower, about $3 \times$ as long as broad. Coloring different: head pale yellowish with dark brown lateral arcs. 1st and 2nd antennal joints dark brown. Pronotum pale grayish with dark brown \pm confluent spots and irroration, the pale color dominating. Scutellum apically and laterally largely pale. Fuscous spots on elytra much larger and evenly distributed; apex and base of cuneus white. Eyes somewhat smaller, ocular

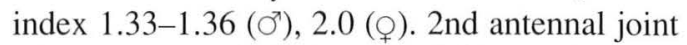
slightly longer, $0.95\left(\sigma^{7}\right)$ or $0.86(Q)$ as long as basal width of pronotum, proportions between joints 15:55:35:? $\left(0^{\Upsilon}\right)$, 15:51:32:20 (Q).

Male genitalia: Vesica in Fig. 4c.

Biology: On Calligonum caput-medusae, $C$. densum and C. setosum (Puchkov 1975:947).

Distribution: Turkestan.

\section{A. basipunctata Wagner}

Fig. $2 \mathrm{p}-\mathrm{x}$

Atomophora basipunctata Wagner 1974:10-11.

The original description: Männchen: 2.8-3.6 $\times$ so lang wie Pronotumbreite. Weisslichgelb mit zerstreuten schwarzen Punkten. Behaarung fein und hell. Scheitel 2.2-2.3 $\times$ so breit wie das Auge, Stirn and Tylus durch eine tiefe Querfurche getrennt. Fühler einfarbig hell, nur das 1. Glied vor der Spitze mit schwarzem Punkt 2. Glied 1.16 $\times$ so lang wie die Pronotumbreite. Pronotum sehr kurz, aber breit, mit wenigen Punkten. Scutellum im basalen Teil dicht mit kräftigen Punkten bedeckt, in hinteren Teil nur mit 2 Punkten nahe der Mitte. Halbdäcken spärlich punktiert, nur das Exocorium mit grösseren, dichter stehenden Punkten. Im Innenwinkel hat das Corium einen grösseren schwarzen Fleck. Cuneus mit einigen feinen roten Punkten. Membran hinter der $\mathrm{Cu}$ neusspitze mit grossem schwarzem Fleck. Das Rostrum reicht weit über die Hinterhüften hinaus. Beine hell, Schenkel vor der Spitze mit schwarzen Punkten, die an der Hinterschenkeln einen Ring bilden. Schienen mit deutlichen schwarzen Punkten. Klauen im Apikalteil strärker gekrümmt. Haftläppchen breit, auf dem Basalhöcker sitzend.

Genitalsegment kurz und breit. Rechtes Paramer breit, fast dreieckig. Linkes Paramer mit stärker gekrümmter, krallenartiger Hypophysis, auf dem Sinneshöcker ein zungenförmiger Fortsatz. Vesica S-förmig, Apikalteil verbreitert, distal eine lange Chitinspitze.

Länge: $\sigma^{7}=2.8-3.0 \mathrm{~mm}$.

Distribution: Known only from Algeria (Chot Merouane, $160 \mathrm{~km} \mathrm{~S}$ von Biskra). 


\section{A. subpallida Wagner}

Fig. 2d-O

Atomophora subpallida Wagner 1965:227-228

The original description: Männchen: Hell rötlichgrau, die für die Gattung charakteristischen Flecke sind stark reduziert und teils schwarzbraun, teils rot. Oberseite mit feinen, gelben, fast anliegenden Haaren. Gestalt länglich-oval. Kopf sehr klein, stark geneigt. Scheitel doppelt so breit wie das Auge. Von vorn gesehen ist der Kopf 1.2 $\times$ as breit wie hoch, unter den Augen verlängert, aber durch die gewölbten Zügel stumpf erscheinend. Fühlergrube an der unteren Augenecke gelengen. Fühler lang und schlank, mit sehr feinen, hellen Haaren. 1. Glied innen mit schwarzem Fleck, etwas kürzer als das Auge breit ist; 2. Glied stabförmig, $0.9 \times$ so lang, wie das Pronotum breit ist; 3 . Glied $0.66 \times$ so lang wie das 2 . und $1.5 \times$ so lang wie das 4., die beiden Endglieder dünner. Pronotum trapezförmig, nach hinten stark verbreitert und dort $1.8 \times$ so breit wie der Kopf samt Augen und $2.3 \times$ so breit wie in der Mitte lang. Seiten gerade, Hinterrand leicht gerundet. Die Fläche des Pronotum mit ungleich grossen und unregelmässig verteilten, schwarzbraunen Flecken und Punkten bedeckt. Scutellum mit nur wenigen schwarzbraunen Flecken. Corium an der inneren Hälfte des Hinterrandes mit grösserem, schwarzen Fleck, im übrigen mit nur wenigen Flecken und Punkten, ebenso der Clavus. Cuneus weisslich, mit Ausnahme einer Zone an der Basis mit roten Punkten bedeckt. Membran hell, dunkel gescheckt. Adern weisslich Unterseite weisslich. Das Rostrum reicht bis zu den Hinterhüften. Beine wissgelb, Schenkel mit unregelmässigen, dunklen Flecken, Dornen der Schienen hell, kürzer als die Schiene dick ist aus kleinen, dunklen Flecken entspringend, Tarsen dick. An den Hintertarsen ist das 3 . Glied $1.2 \times$ so land wie das 2 . und dieses wiederum $1.4 \times$ so lang wie das 1 . Klauen sehr klein, distal stark gekrümmt, Haftläpchen sehr breit, aber kurz, seine Spitze ist von der Klauenspitze um etwas mehr als die Länge des Haftläpchens entfernt.

Genitalsegment des $\sigma^{7}$ breiter als lang, abgerundet kegelförmig mit feiner Behaarung und einzelnen längeren Haaren. Unterseite mit starker, kielartiger Falte, an der linken Seite mit einer Gruppe kleiner Zähne. Rechtes Paramer klein, geschweift, Hypophysis klein und stark gekrümmt. Linkes Paramer mit langer, dikker, gekrümmter Hypophysis, über die der Paramerenkörper höckerartig hinausragt, Sinneshöcker kurz und spitz. Vesika des Penis klein, robust, U-förmig gekrümmt, distal mit sehr langer, leicht gekrümmter Chitinspitze. Apikalteil der Theka wenig gekrümmt, distal spitz.

Länge: $\sigma^{7}=2.95 \mathrm{~mm}$.

Distribution: Known only from Algeria (Biskra).

\section{Genus Camptotylidea Wagner}

Camptotylidea Wagner 1957:92-93. Type species: C.persica Wagner.

Diagnosis: Color greenish or yellowish. Upper surface usually with small dark spots. Head in lateral view higher than long. Claws slender, basal tooth obtuse; pulvilli long, elongate, extending beyond middle of claw. Hind tarsus gracile, apex of 2nd joint sharply triangular.

Color: Greenish, yellowish or whitish. Upper surface with fuscous or orangish dotting on elytra, sometimes also on pronotum and scutellum, the dark dots rarely (in astarte) very faint. If major dark markings exist, they form two longitudinal bands on the pronotum, one spot on the clavus and one spot on the basal part of the mesocorium. Several species are ornamented by a black spot on the apical margin of the corium. Antennae pale, 1 st joint often with reddish or brown subapical dots, 2nd joint uniformly pale or (in lineata) ornamented with dark brown spots. Legs pale, femora rarely (in lineata and vitticollis) with dark markings. Tibiae generally uniformly pale, sometimes with indistinct, rarely with distinct (lineata and vitticollis) dark spots. Tibial spines delicate, pale.

General structure as in Atomophora, but claws (Fig. 4d-f) different: slender, basal tooth obtuse, pulvilli long, elongate, extending beyond middle of claw.

Male genitalia as in Atomophora.

Biology: On desert shrubs such as Alhagi maurorum, Astragalus and Haloxylon persicum.

Distribution: Irano-Turanian, extending from Israel and Saudi Arabia to Turkestan and Transcaspia. 


\section{Key to the species of Camptotylidea}

1. 2nd antennal joint (Fig. 5h) with dark spots .. lineata

- 2nd antennal joint uniformly pale ........................... 2

2. Upper surface pale grayish or yellowish, with slight greenish tinge. Pronotum never with dark longitudinal bands. Clavus and corium, often also pronotum, scutellum and cuneus, with regular fuscous dotting. Inner apical angle of corium often with compact blackish spot

.. 3

- Coloring different ....................................................... 8

3. Corium without conspicuous black apical spot ....... 5

- Corium with compact blackish apical spot ............. 6

4. Body long, length $4.0-4.25 \mathrm{~mm}$, and elongate. 2nd antennal joint nearly $1.5\left(\sigma^{7}\right)$ or $1.35-1.41(q) \times$ as long as diatone ................................................ albovittata

- Body smaller, length $<4 \mathrm{~mm}$, and robuster. 2nd antennal joint shorter.

5. Membrane of elytra immaculate, whitish hyaline. Eyes large, ocular index 1.10-1.24 ( ( $)$ ) 1.41-1.82 (O) ....... .. alba

- Membrane of elytra smoky with faint fuscous mottling. Eyes smaller, ocular index 1.54-1.60 ( $\left.0^{3}\right)$, $2.30-2.55$ (o) .......................................... astragalii

6. Cuneus immaculate, clavus and corium with sparse and faint fuscous dotting (Fig. 5a) .......... bipunctata

- Clavus, corium and cuneus with distinct \pm dense fuscous dotting

7. Body $\left(0^{7}\right)$ gracile, parallel-sided. Eyes large, ocular index 1.55-1.64. Frons moderately convex. 1st antennal joint uniformly pale persica

- Body robuster, elongately ovate. Eyes small, ocular index $2.0\left(\sigma^{7}\right), 2.21-2.47$ (Q). Frons conspicuously convex. 1st antennal joint with faint incomplete dark subapical ring .................................................. bast

8. Pronotum with two longitudinal fuscous bands. If these absent (fuscomaculatus), then scutellum with $\mathrm{X}$-shaped dark figure and pattern of elytra as in Fig. 5f. ......

\section{... 9}

- Pronotum without dark longitudinal bands .......... 11

9. Small species, length $2.75-3.0 \mathrm{~mm}$. Longitudinal dark bands on pronotum \pm faint, not sharply delimited ..... modesta

- Larger species, length at least $3.75 \mathrm{~mm}$................ 10

10. Femora with conspicuous blackish markings, tibiae with distinct dark dots vitticollis

- Legs uniformly pale .......................... fuscomaculata

11. Color whitish yellow, pale greenish in life. Corium without dark apical spot, dark dotting on elytra very faint or even absent ...................................... astarte

- Color not greenish. Inner apical area of corium with fuscous figure

12. Commissural margin of clavus dark brown (Fig. 5d), clavus with distinct dense dark fuscous dotting suturalis

- Not as above ......................................................... 13

13. Bright yellow owing to dense \pm confluent orangish or bright yellow irroration on upper surface. Tibiae with small dark dots alhagii

- Pale species. Tibiae immaculate 14
14. Very pale, whitish yellow; very faint brownish or fulvous band on clavus and along claval suture on corium; medioapical angle of corium with faint fuscous spot; orangish irroration on elytra very faint. Eyes very small, ocular index 1.64-1.73 (०), 2.30-2.54 (o) candida

- No longitudinal infumations on clavus or the adjacent part of corium; elytra with \pm dense orangish mottling. Eyes much larger..... 15

15. Body narrow, elongate, $3.3-3.6 \times$ as long as broad. Extremities long and gracile; hind tibia about 1.7-1.8 $x$ as long as basal width of pronotum .........flavescens

- Body broadly ovate, 2.8-3.0 $\times$ as long as broad. Extremities shorter; hind tibia about $1.6 \times$ as long as basal width of pronotum pallescens

\section{C. alba (Reuter), comb. n.}

\section{Atomophora alba Reuter 1879:290}

Types studied: Turkestan, Cardara, 20 syntypes, one of them designated here as the lectotype, in coll. Reuter in Mus. Helsinki.

Material studied: USSR: Akr-Tjubje, Aujatshjeat, 2 exx, 5.VII.1930 Bianki; Dzjebjed, Turkmen., 3 exx, 3.VI.1934, V.Popov; Repetek, Kara-Kum, 1 ex, 25.IV.1947, L. Arnoldi, in coll. Linnavuori.

Diagnosis: Upper surface with regular fuscous dotting. Membrane whitish, immaculate. Body relatively robust. Antennae shortish, 2nd joint $1.08-1.12\left(\mathrm{O}^{7}\right), 1.11-1.20(\mathrm{Q}) \times$ as long as diatone. Eyes largish, ocular index (ơo) 1.10-1.20.

Length $3.0-3.5 \mathrm{~mm}$. Whitish ochraceous. Head and pronotal calli with yellowish tinge. Eyes pale gray or brownish gray. Antennae uniformly pale yellow-brown. Basal part of pronotum and apical part of scutellum with small fuscous dots. Clavus, corium and cuneus with dense fuscous dotting; membrane immaculate, whitish hyaline. Legs pale yellow-brown, under surface of femora with indistinct brown mottling. Tibiae with tiny dark dots.

Body relatively robust. Eyes largish, ocular

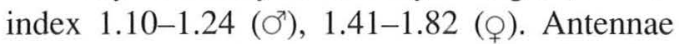
relatively short, in $\sigma^{\prime}$ incrassate; proportions be-

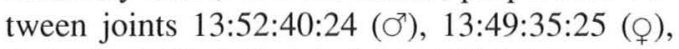

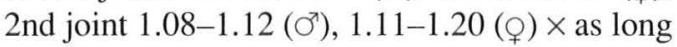
as diatone.

Biology: On Ammodendron conollyi and A. kareli (Puchkov 1975:946).

Distribution: Turkestan. 


\section{C. albovittata (Reuter), comb. n.}

\section{Atomophora albovittata Reuter 1904:14.}

Types studied: Turkestan, Aschabad, 1 ị syntype, designated here as the lectotype, $10^{7}$ (fragmentary) syntype, 1 syntype (fragmentary, only one leg present), Ahnger, in Mus. Helsinki.

Material studied: USSR: Transcaspia, 10 $0^{7}$, collector unknown, in coll. Linnavuori.

Diagnosis: Like C. alba, but membrane embrowned with pale mottling. Body elongate. Antennae long, 2nd joint $1.5\left(0^{7}\right)$ or 1.35-1.41 (Q) $\times$ as long as diatone. Eyes smaller.

Length 4.0-4.25 mm. Coloring as in C. alba, but membrane of elytra faintly embrowned with pale mottling.

Body larger and more elongate. Eyes smaller, ocular index 1.43-1.50 (o'), 2.0-2.08 (Q). 2nd antennal joint nearly $1.5\left(0^{7}\right)$ or $1.35-1.41(Q) \times$ as long as diatone; proportions between antennal joints 15:68:52:25 (ơ), 16:69:? (Q).

Biology: On Astragalus transcaspicus and related species (Puchkov 1975:946).

Distribution: Turkestan.

\section{C. astragalii (Linnavuori), comb. $\mathrm{n}$.}

Fig. $7 \mathrm{k}-\mathrm{r}$

\section{Atomophora astragalii Linnavuori 1986:155-156.}

Types studied: Saudi Arabia, 50 km NW of An Nu'ayriyah, male holotype and numerous paratypes, 23.V.1978, Linnavuori, in coll. Linnavuori.

Diagnosis: Like C. alba, but membrane smoky with fuscous mottling. Ocular index 1.54-1.60 ( $\left.0^{7}\right), 2.30-2.55$ (ㅇ).

Length: $3.25-3.75 \mathrm{~mm}$. Opaque. Whitish with slight yellowish or greenish tinge. Frons with yellow lateral arcs; eyes grayish. Antennae yellowish, 1st joint with very faint brownish subapical dot. Pronotum with percurrent whitish median stripe, faint poorly delimited yellowish areas at calli and along lateral and basal margin, and with small faint fuscous dots on posterior part of disk, best visible at humeral angles. Scutellum with faint pale yellow markings on either side of pale midline. Clavus, corium and cuneus whitish, densely and regularly ornamented with round fuscous dots; membrane smoky with faint fuscous mottling, veins whitish or yellowish. Under surface pale, immaculate. Legs ochraceous, femora and tibiae with minute \pm dense fuscous dots.

$\sigma^{7}$ elongate, $\bigcirc$ elongately ovate. Hair covering on upper surface longish, whitish, semierect. Head about $0.7 \times$ as broad as basal width of pronotum; ocular index 1.54-1.60 (ơ), 2.30-2.55 (Q). Antennae longish and gracile, proportions between

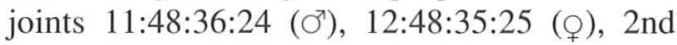

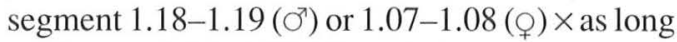
as diatone, $0.82-0.89\left(\widetilde{O}^{7}\right)$ or $0.72(\bigcirc) \times$ as long as basal width of pronotum. Rostrum extending to near middle coxae. Pronotum about $2.2\left(\sigma^{7}\right)$ or 2.4 (Q) $\times$ as broad as long in middle. Tibial spines delicate, pale. Claw in Fig. 7p.

Male genitalia in Fig. 7m-r.

Biology: On Astragalus spinosus.

Distribution: Known only from Saudi Arabia.

\section{C. bipunctata (Reuter), comb. $\mathbf{n}$.}

Fig. 5a

\section{Atomophora bipunctata Reuter 1901:179.}

Type studied: Turcmenia, 1 syntype (damaged, only one leg left), J. Sahlberg, in Mus. Helsinki.

Material studied: USSR: Turkmenskaja SSR, Repetekskii z-k., 2ơo, 14.IX.1976, Puchkov, in coll. Linnavuori.

Diagnosis: Corium with compact blackish subapical spot. Dark spotting on elytra sparse and faint, cuneus immaculate.

Length $3.0-3.25 \mathrm{~mm}$. Pale yellow with slight greenish tinge. Eyes grayish brown. Antennae pale yellow. Clavus and corium with sparse faint fuscous dotting, apical margin of mesocorium with well-delimited blackish spot, cuneus immaculate; membrane milky hyaline with two fuscous spots at apex of cuneus, smoky dashes along veins in cells and a smoky subapical mark arising from lateral margin. Legs pale yellow, tibiae with very indistinct brown dots.

Body small, relatively robust, elongately ovate. Ocular index 2.1-2.21 (Q). Proportions between antennal joints 12:45:32:21, 2nd joint 1.13-1.28 $\times$ as long as diatone.

Biology: On Haloxylon aphyllum and H.persicum (Puchkov 1975:947).

Distribution: Turkestan. 

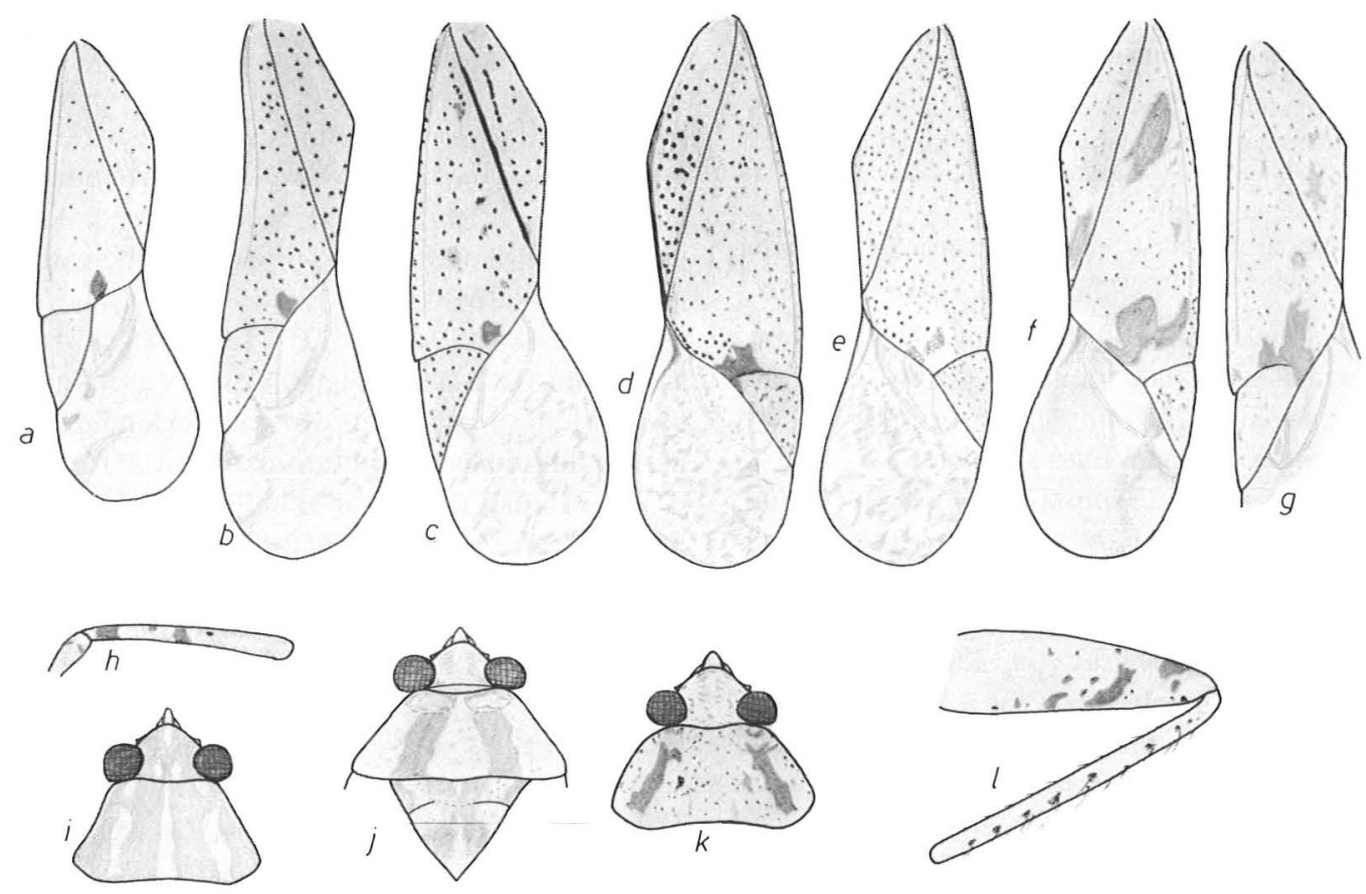

Fig. 5. Elytron. a: Camptotylidea bipunctata (Reuter); b: C. persica Wagner; c: C. lineata (Reuter); d: C. suturalis (Reuter); e: C. alhagii (Linnavuori); f: C. fuscomaculata (Reuter); g: C. vitticollis (Reuter). - C. lineata (Reuter). h: antenna; i: head and pronotum, dorsal view. - C. fuscomaculata (Reuter). j: head and pronotum, dorsal view. $-C$. vitticollis (Reuter). $\mathrm{k}$ : head and pronotum, dorsal view; l: hind leg.

\section{C. persica Wagner}

Figs. 5b, 6a-c

\section{Camptotylidea persica Wagner 1957:93-94.}

Types studied: Iran Baluchistan, Iranshar, $800 \mathrm{~m}, 30^{\circ}$ paratypes 1-10.IV.1954, Richter \& Schäuffele, in Mus. Hamburg and coll. Linnavuori.

Diagnosis: Like $C$. bipunctata, but clavus, corium and cuneus with distinct \pm dense fuscous dotting. Body $\left(\mathrm{O}^{7}\right)$ gracile, parallel-sided. Eyes large, ocular index 1.55-1.64. Frons moderately convex. 1 st antennal joint uniformly pale.

Length $2.5-3.0 \mathrm{~mm}$. Yellowish gray with slight greenish tinge. Eyes brown. Lateral arcs on frons, base of vertex and calli of pronotum yellow. Antennae yellowish. Elytra pale grayish, partially with slight fulvous tinge, apical angle of mesocorium with conspicuous dark brown spot, clavus, corium and cuneus with dilute fuscous dots; membrane whitish with very faint brown irroration, lateral margin with two immaculate patches, delimited by obscure fuscous spots. Under surface and legs pale yellowish; under surface of femora with faint brown spots; tibiae with very small brown spots.

$\checkmark$. Body gracile, parallel-sided. Head $0.77-0.81$ $x$ as broad as basal width of pronotum, frons moderately convex; eyes large, ocular index 1.55-1.64, in $\varnothing$ according to Wagner 2.8. Proportions between antennal joints 14:65:45:?, 2nd joint $1.63 \times$ as long as diatone, $1.25 \times$ as long as basal width of pronotum. Rostrum extending to hind coxae. Pronotum about $2.17 \times$ as broad as long in middle.

Male genitalia (Fig. 6a-c): Vesica narrow, apex slightly bifid.

Distribution: Iran. 


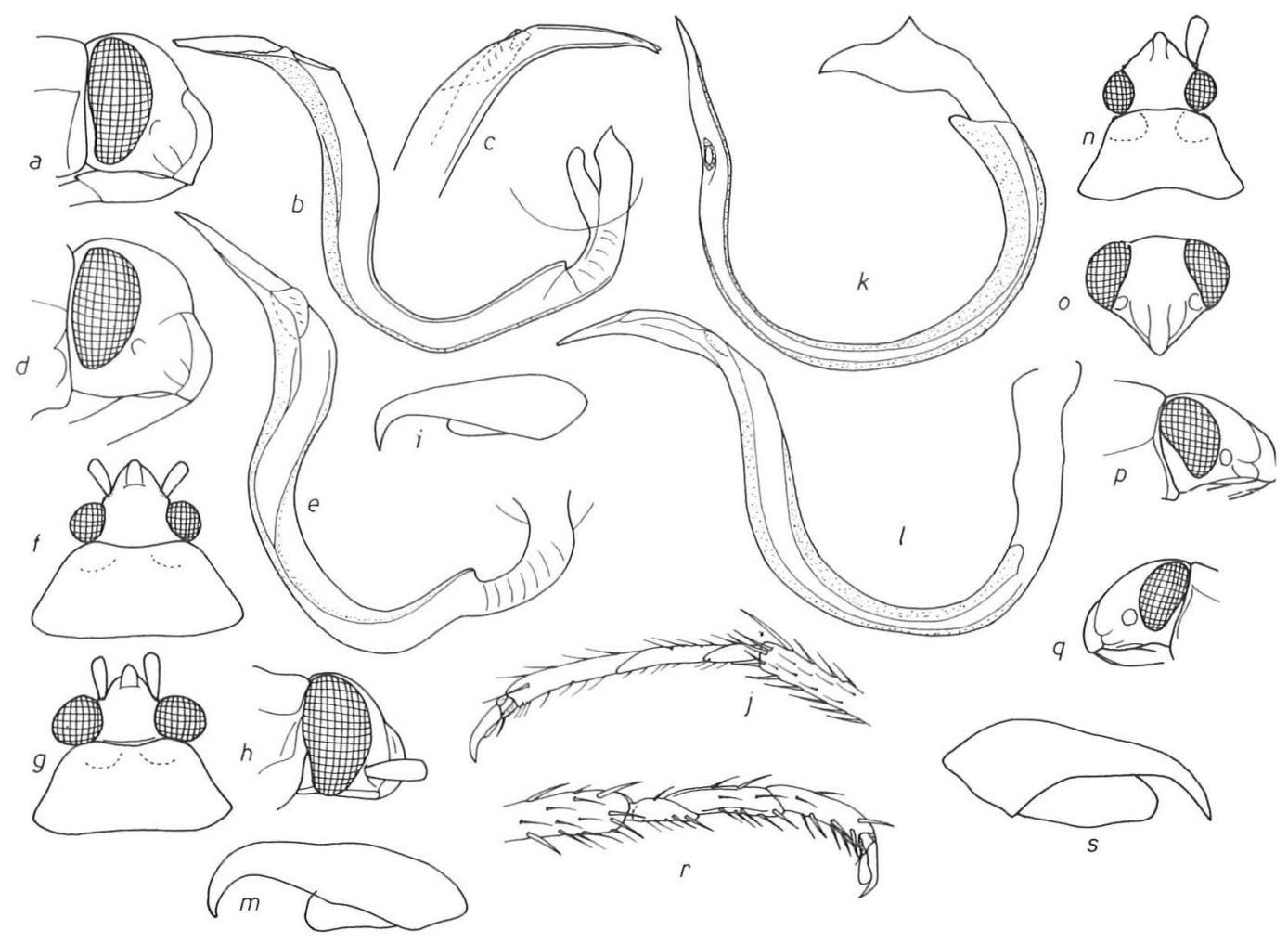

Fig. 6. Camptotylidea persica Wagner. a: male head, lateral view; b-c: vesica of two specimens. $-C$. bast (Linnavuori). d: male head, lateral view; e: vesica. - C. candida (Linnavuori). f: male head and pronotum, dorsal view. - C. astarte (Linnavuori) (ex from Israel). g: male head and pronotum, dorsal view; h: male head, lateral view; i: claw; j: hind tarsus. - C. fuscomaculata (Reuter). $\mathrm{k}-\mathrm{l}$ : vesica (exx from Repetek and Ukhaidir). $-C$. vitticollis (Reuter). m: claw. - Taeniophorus hyalinus Linnavuori. n: male head and pronotum, dorsal view; o: male head, apical view; p-q: male and female head in lateral view; r: hind tarsus; s: claw.

\section{C. bast (Linnavuori), comb. $\mathrm{n}$.}

Fig. 6d-e

Atomophora bast Linnavuori 1989:51-53.

Types studied: Israel, Southern District, Yotvata, female holotype, 2o paratypes, 24.IV.1986, Linnavuori, in coll. Linnavuori.

Material studied: The same locality, 10', 15.IV.1986, Linnavuori.

Diagnosis: Like C . persica, but body robuster, elongately ovate. Eyes small, ocular index 2.0 (ơ), 2.21-2.47 (Q). Frons distinctly convex. 1st antennal joint with faint dark subapical ring.

Length $3 \mathrm{~mm}$. Like the preceding species but body in male broader, elongately ovate. Head 0.74 $\times$ as broad as base of pronotum; eyes much smaller, ocular index 2.0; frons more convex. 1st antennal segment with incomplete dark apical ring.

Measurements: Head in $\odot 0.63-0.67 \times$ as broad as basal width of pronotum; ocular index 2.21-2.47. Proportions between antennal joints 14:65:41:25 ( ( ) $), 12: 48: 34: 21(\bigcirc), 2$ nd joint 1.63 $\left(\sigma^{7}\right)$ or 1.20-1.34 $(\circ) \times$ as long as diatone, $1.20 \times$ as long as basal width of pronotum. Pronotum 2.35-2.40 $\times$ as broad as long in middle.

Male genitalia: Vesica (Fig. 6e) robuster than in $C$. persica, apex needle-like.

Biology: On Bassia muricata in sandy habitats.

Distribution: Israel (the Negev). 
C. lineata (Reuter), comb. $\mathrm{n}$.

Figs. $5 \mathrm{c}, \mathrm{h}-\mathrm{i}$

Atomophora lineata Reuter 1901:178.

Types studied: Turkmenia, 2 o syntypes, one of them designated here as the lectotype, J. Sahlberg, in Mus. Helsinki.

Material studied: USSR: st. Džebel, Turkmen., 1 ex, 17.VI.1934, V. Popov; Imam-baba Merw u. Zakasts.o., 1 ex, 23.IV.1912, Kožančikov, in coll. Linnavuori.

Diagnosis: Easily recognized by the maculate 2nd antennal joint.

Length 3.0-3.25 mm. Pale yellowish or greenish. Median stripe on tylus and on frons, mediobasal spots on vertex, three longitudinal bands on pronotum, lateral margins of pronotum, and faint median stripe on scutellum whitish. Eyes brownish. Antennae yellowish brown, 1st joint with incomplete dark subapical ring, 2nd joint with distinct fuscous spots. Clavus, corium and cuneus with dense fuscous dotting, corium also with \pm developed faint largish brownish spots, claval suture fuscous, \pm distinct brown stripe along lateral puncture row on clavus, apical margin of mesocorium with conspicuous black spot; membrane whitish hyaline with \pm abundant pale brownish mottling. Legs yellowish, apices of femora with distinct dark brown spots; tibiae with distinct small dark dots.

Body small, elongately ovate. Ocular index about $1.36\left(\sigma^{7}\right), 1.78-2.0($ (o). 2nd antennal joint $1.14\left(\sigma^{3}\right)$ or $1.18(0) \times$ as long as diatone.

Biology: On Tournefortia sogdiana, Heliotropium arguzioides and $H$. turcomanica $(\mathrm{Pu}-$ chkov 1975:946).

Distribution: Turkestan.

\section{C. suturalis (Reuter), comb. n.}

Figs. 4e, 5d, 7u

\section{Atomophora suturalis Reuter 194:13.}

Types studied: Turkestan, Aschabad, 40 syntypes, one of them designated here as the lectotype, Ahnger, in Mus. Helsinki.

Material studied: USSR: Turkestan, Aschabad, Ahnger; Buchara mer. Termez, 3 exx, 20.VI.1912, Kiritshenko. Iran: Iranshar, 800 m, 3 exx, 11-21.IV.1954, Richter \& Schäuffele, in coll. Linnavuori; Sistan, Kuh-e Khajh, 2 exx, 5.X.1877, A. Vigna, coll. Carapezza.
Diagnosis: Upper surface whitish or orangish yellow with orangish spots. Commissural margin of clavus dark brown, clavus with dense dark dotting. Tibiae immaculate.

Length 3.25-3.5 mm. Whitish or orangish yellow. Head and pronotum with faint orangish spots. Eyes brown. Antennae pale yellowish. Scutellum, save basal lateral angles and a faint median stripe on apical part, infumed with minute dark dots. Elytra whitish or orangish yellow, commissural margin of clavus dark brown, clavus otherwise with distinct dense dark brown dotting, only base and lateral margin immaculate; medioapical area of corium whitish with irregularly shaped largish dark fuscous spot and minute dark irroration, rest of corium and cuneus immaculate or with indistinct orangish mottling; membrane whitish with abundant brownish mottling. Legs yellow, immaculate.

Body narrowish. Ocular index about $1.22\left(\sigma^{3}\right)$ or 1.90-2.21 (Q). Antennae gracile, 2nd joint about $1.26\left(\sigma^{\top}\right)$ or $1.34-1.38(0) \times$ as long as diatone.

Male genitalia: Vesica in Fig. 7u.

Distribution: Irano-Turanian.

\section{C. alhagii (Linnavuori), comb. $\mathbf{n}$.}

Figs. $5 \mathrm{e}, 7 \mathrm{t}$

Atomophora alhagii Linnavuori 1986:155.

Types studied: Iraq, near Ana, female holotype and several paratypes, 8.X.1979, Linnavuori; Tharthar lake, 1 paratype, 23.VIII.1979, Linnavuori. Saudi Arabia, Al Hasa, several paratypes, 24.X.1977, Linnavuori, in coll. Linnavuori.

Diagnosis: Upper surface bright yellowish with dense and \pm confluent orange irroration. Commissural margin of clavus pale, fuscous dots only on tip of clavus and inner apical area of corium. Tibiae with small dark dots.

Length $3.0-3.75 \mathrm{~mm}$. Pale or bright yellow. Upper surface with dense \pm confluent orange irroration, posterior part of pronotum and base of corium often also with a few dilute fuscous dots. Head, pronotum and scutellum with faint narrow pale median stripe. Eyes reddish gray. Antennae yellow, 1st joint with faint brown subapical spot, 4 th joint slightly infumed. Extreme tip of clavus 
and inner apical area of corium milky with fuscous dots; membrane milky with very dense fuscous irroration, veins yellowish. Under surface with orangish tinge. Legs fulvous, femora and tibiae with very small brown dots.

Body robust, parallel-sided, 3.1-3.5 $\times$ as long as broad at base of pronotum. Hair covering long, dense, semierect, and yellowish. Head $0.68-0.71 \times$ as broad as basal width of pronotum, ocular index 1.21-1.26 (ơ), $1.90(0)$. Proportions between antennal joints 5.5:21:16:11 ( $\left(^{7}\right)$, 5.5:20:15:11 (@), 2nd segment $1.14\left(\sigma^{7}\right)$ or $1.21-$ $1.26($ (Q) $\times$ as long as diatone. Rostrum extending to middle coxae. Claw in Fig. 4d.

Male genitalia: Vesica in Fig. 7t.

Biology: On Alhagi maurorum.

Distribution: Known from Iraq and Saudi Arabia.

\section{C. candida (Linnavuori), comb. n. \\ Figs. 4f-i, $6 f$}

Atomophora candida Linnavuori 1984:40-41.

Types studied: Iraq, Karbala, Ukhaidir-Nukhaib, female holotype, 3 paratypes, 2.V.1980; Nukhaib-km 160, several paratypes, 3.4.1980, Linnavuori, in coll. Linnavuori.

Diagnosis: Opaque. Very pale, whitish yellow. Very faint brownish or fulvous band on clavus and along claval suture on corium; medioapical angle of corium with faint fuscous spot. Orangish irroration on elytra very faint. Tibiae immaculate. Eyes very small, ocular index $1.64-1.73\left(0^{7}\right), 2.30-2.54$ (ф).

Length $2.75-3.25 \mathrm{~mm}$. Opaque. Whitish yellow. Antennae whitish ochraceous, immaculate. Eyes pale grayish. Apical two-thirds of clavus and medioapical area of corium slightly embrowned, inner apical angle of corium with a dilute fuscous spot extending to inner basal angle of cuneus, corium and cuneus also with slight trace of orangish dots; membrane milky, with dense fuscous irroration, immaculate spot near apex of cuneus. Legs uniformly whitish ochraceous.

Body parallel-sided, about $3 \times$ as long as broad at base of pronotum. Hair covering long, whitish. Head $0.72-0.73\left(\sigma^{7}\right)$ or $0.65($ ( ) $) \times$ as broad as basal width of pronotum; ocular index 1.64-1.73 $\left(\sigma^{7}\right)$, 2.30-2.54 (o). Antennae gracile, proportions between joints 12:46:37:23 ( $\left.\bigcirc^{7}\right), 12: 50: 37: 22($ (Q),

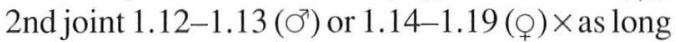
as diatone, $0.81-0.82\left(0^{7}\right)$ or $0.74-0.77(\circ) \times$ as long as basal width or pronotum. Rostrum extending to hind coxae. Pronotum $2.3-2.4 \times$ as broad as long in middle. Claw in Fig. 4j.

Male genitalia in Fig. 4g-i.

Biology: On Ephedra foliata.

Distribution: Iraq.

\section{C. flavescens (Puchkov), comb. n.}

Fig. 7a-d

Atomophora flavescens Puchkov 1976:654-656.

Material studied: USSR: Repetek, Karakum, 1 ex, 10.V.1938, Pežitnova; Turkmeniskaja SSR, Repeteskii e-k., 4 exx, 13-23.IX.1976, Puchkov, in coll. Linnavuori.

Diagnosis: Pale yellowish-ochraceous. Pronotum and scutellum with faint orangish irroration. Elytra with \pm dense orangish mottling; inner apical angle of corium with one large and one small dark spot. Tibiae immaculate. Body elongate, $3.3-3.6 \times$ as long as broad. Extremities long and gracile.

Length $2.75-3.25 \mathrm{~mm}$. Pale yellow-ochraceous. Eyes gray. Antennae whitish yellow. Pronotum and scutellum with faint orangish irroration. Clavus, corium and cuneus with dense orangish mottling, inner apical angle of corium with minute fuscous dots and one large and one small dark brown spot; membrane milky with dense brown mottling. Legs whitish yellow; tips of hind femora with orangish tinge, tibiae immaculate.

Body $3.3-3.6 \times$ as long as broad, elongately ovate. Ocular index $1.10\left(\mathrm{O}^{7}\right), 2.0-2.25$ (६). Extremities long and gracile. 2nd antennal segment in $\sigma^{7}$ about 1.36 , in $ᄋ 1.17 \times$ as long as diatone. Hind tibia about $1.73-1.85 \times$ as long as basal width of pronotum.

Male genitalia: Vesica in Fig. 7d.

Biology: On Haloxylon aphyllum.

Distribution: Turkestan. 

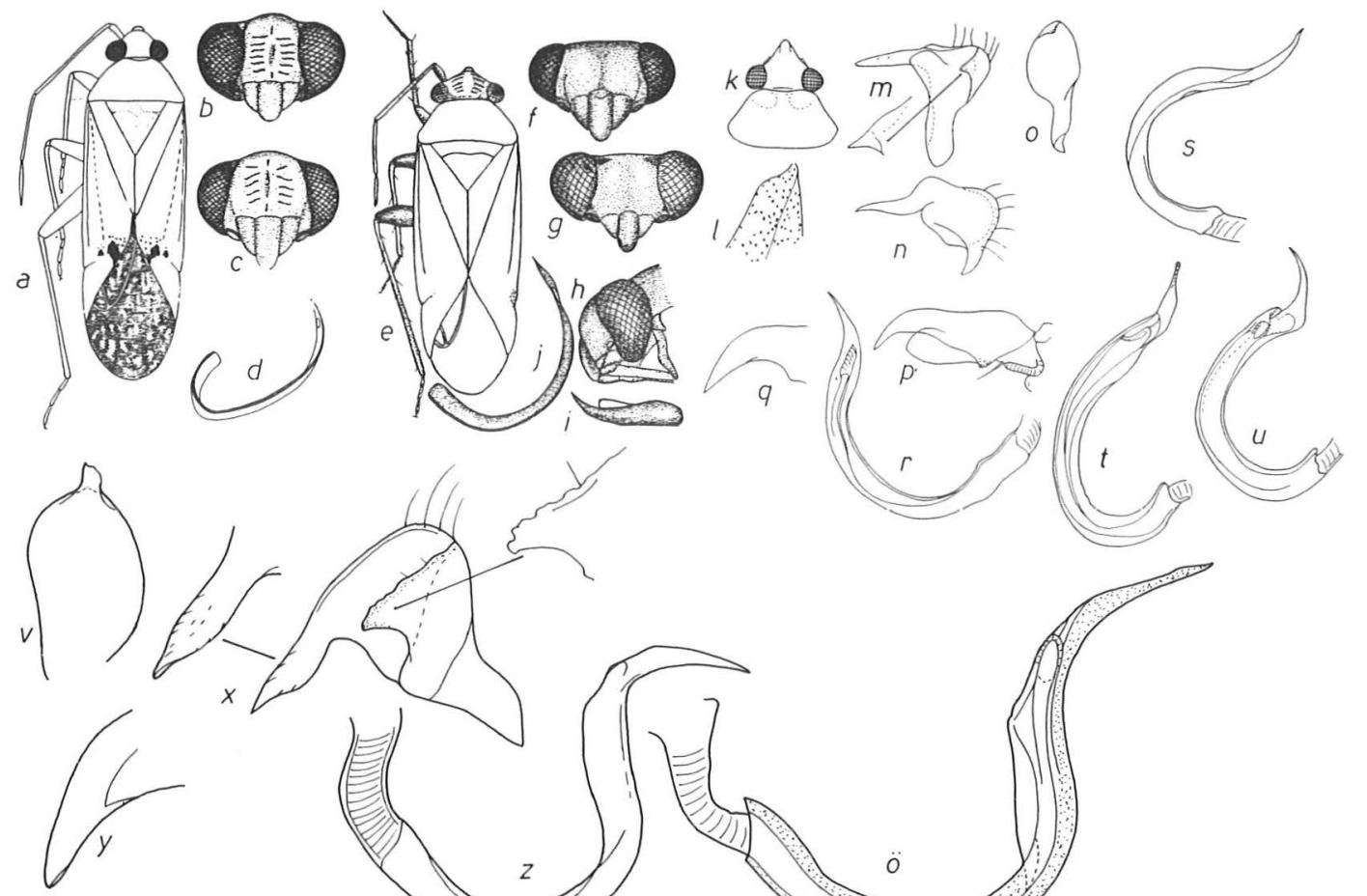

Fig. 7. Camptotylidea flavescens (Puchkov). a: male, dorsal view; b-c: male and female head; apical view; d: vesica. - C. pallescens (Puchkov). e: male, dorsal view; $f-g$ : male and female head, apical view; $h$ : male head, lateral view; i: claw; j: vesica. $-C$. astragalii (Linnavuori). k: male head and pronotum, dorsal view; I: base of elytron; m: left style; o: right style; p: claw; q: theca; r: vesica. - C. modesta (Linnavuori). s: vesica. - C. alhagii (Linnavuori). t: vesica. - C. suturalis (Reuter). u: vesica. - Taeniophorus hyalinus Linnavuori. v: right style; $x$ : left style; y: theca; z-ö: vesica (in glycerine and in slide mount). — a-j after Puchkov 1976, k-u after Linnavuori 1986.

\section{C. pallescens (Puchkov), comb. n.}

Fig. $7 \mathrm{e}-\mathrm{j}$

\section{Atomophora pallescens Puchkov 1976:653-654.}

Material studied: USSR: Turkmenskaja SSR, Dzebela, Krasnovodska Molla-Kari, 200, 26.V.1975, Puchkov, in coll. Linnavuori.

Diagnosis: Like C.flavescens, but paler, orangish irroration very faint. Body broadly ovate, $2.8-3.0 \times$ as long as broad. Extremities shorter.

Length $2.75-3.0 \mathrm{~mm}$. Like the preceding species, but ground color paler, whitish ochraceous, orangish irroration faint. Body much broader, broadly ovate, $2.8-3.0 \times$ as long as broad. Extremities shorter, 2nd antennal joint in $९$ a little shorter than diatone, hind tibia in $\varnothing$ about $1.58 \times$ as long as basal width of pronotum. Ocular index 1.1-1.25 (o), 1.9-2.09 (Q). Claw in Fig. 7i.

Male genitalia: Vesica in Fig. 7j.

Biology: On Haloxylon persicum.

Distribution: Turkestan.

\section{C. astarte (Linnavuori) comb. $\mathrm{n}$.}

Figs. $6 \mathrm{~g}-\mathrm{j}, 8 \mathrm{a}-\mathrm{j}$

Atomophora astarte Linnavuori 1971:3

Taeniophorus grandoculus Linnavuori 1984:43, syn. n.

Types studied: Israel, Eilat, male holotype and 1 paratype of astarte. 10.VI.1958, Linnavuori. Iraq, Dhi Ghar, Nasiriyah-Abu Ghar, male holotype and many paratypes of 

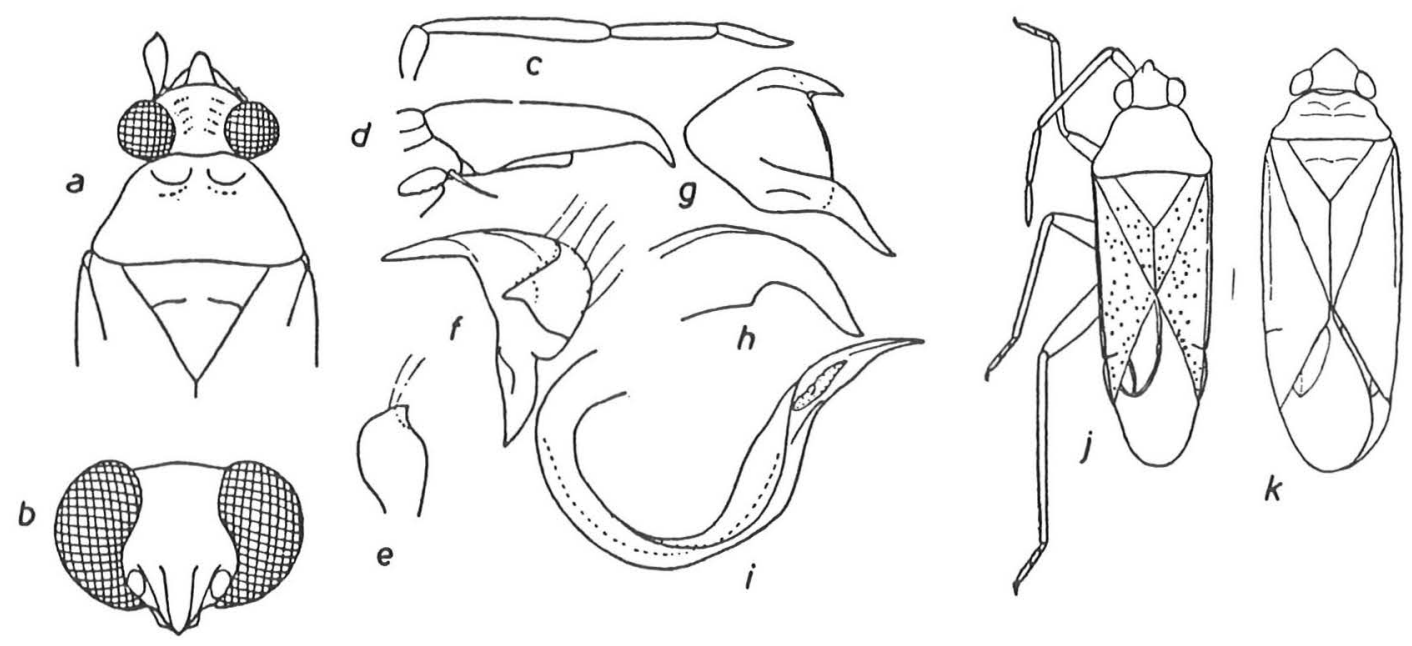

Fig. 8. Camptotylidea astarte (Linnavuori) (ex from Iraq). a: male head and thorax, dorsal view; b: male head in apical view; c: male antenna; d: claw; e: right style; f-g: left style; h: theca; i: vesica. - Taeniophorus hyalinus Linnavuori. j-k: male and female in dorsal view. - After Linnavuori 1952 and 1984, and Puchkov 1975.

grandoculus, 15.IV.1980 and 31.III.1981, Linnavuori, in coll. Linnavuori.

Material studied: Saudi Arabia: Haradh, 1 ex, 30.III.1978; $70 \mathrm{~km} \mathrm{~N}$ of Salwah, 1 ex, 15.V.1978; $50 \mathrm{~km} \mathrm{~N}$ of Urayrah, several exx, 12.IV.1978, Linnavuori. Israel: the Negev, Elifaz near Timna, 3 exx, 23.VI.1986, Linnavuori, in coll. Linnavuori.

Diagnosis: Whitish yellow or greenish. Corium without dark apical spot. Dark dotting on elytra very faint or absent. Tibiae immaculate. Eyes in $\sigma^{7}$ voluminous, ocular index $0.90-1.04$ (○), 1.64-1.80(ф).

Length $\sigma^{7} 3.5-3.75 \mathrm{~mm}$, o $2.75-3.25 \mathrm{~mm}$. Shiny. Whitish or pale greenish yellow. Eyes reddish gray. Antennae yellow. Elytra uniformly pale or with indistinct dark dots; membrane pale hyaline, veins pale. Legs pale, immaculate.

Body $3.1\left(\sigma^{7}\right)$ or $2.7(q) \times$ as long as broad at base of pronotum. Hair covering rather sparse, short, pale. Head in $\sigma^{7} 0.82$, in $q 0.73-0.74 \times$ as broad as basal width of pronotum; eyes in $0^{7}$ voluminous, in $९$ somewhat smaller, ocular index 0.90-1.04 ( ( $\left.0^{7}\right), 1.64-1.8(0)$. Antennae relatively short, in $0^{7}$ incrassate, in o slenderer, proportions between joints 6:24:15:9 ( $\left.\sigma^{\top}\right), 6: 24: 15: 10(0), 2$ nd

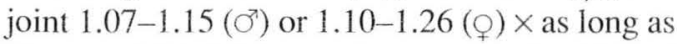
diatone, $0.81-0.94 \times$ as long as basal width of pronotum. Rostrum extending to base of middle coxae. Claws in Fig. 6i, pulvilli narrow.

Male genitalia in Fig. 8e-j.

Biology: On Haloxylon persicum.

Distribution: Irano-Turanian, recorded from Israel, Saudi Arabia and Iraq. Dr. I. M. Kerzhner has informed me that the species also occurs in Turkestan.

\section{C. modesta (Linnavuori), comb. n.}

Fig. 7s

Atomophora modesta Linnavuori 1986:157.

Types studied: Saudi Arabia, Hufuf, male holotype, several paratypes, 23.IV-13.V.1978, Linnavuori, in coll. Linnavuori.

Diagnosis: Subopaque, whitish. Pronotum with faint dark sublateral bands. Elytra with dense faint dilute fuscous or orangish irroration, apical margin of mesocorium with transverse fuscous spot. Legs immaculate. Small, length 2.75-3.0 mm.

Length 2.75-3.0 mm. Subopaque. Whitish. Vertex with faint orange spot near each eye, frons with fulvous lateral arcs. Eyes pale grayish or reddish. Antennae pale ochraceous. Pronotum 
with faint fulvous or brownish sublateral bands with sparse brownish irroration extending from anterolateral angles to basal margin; middle of disk immaculate or with two faint longitudinal orangish stripes, in $q$ entire disk with faint brownish irroration. Scutellum with basal angles orangish, middle of apical part, excluding pale midline, slightly infumed or orangish and provided with a few tiny fuscous dots. Clavus, corium and cuneus with dense faint dilute fuscous and orangish irroration, apical margin or mesocorium with transverse fuscous spot; membrane brownish with pale irroration. Femora pale orangish, tibiae pale ochraceous, immaculate.

Small, parallel-sided. Head $0.85\left(0^{7}\right)$ or 0.70 $(\circ) \times$ as broad as basal width of pronotum; ocular index 1.21-1.50 ( $\left(\mathrm{O}^{7}\right), 2.15(\mathrm{Q})$. Proportions between antennal joints 11:50:35:20 ( $\left(^{7}\right), 11: 45: 31: 20$

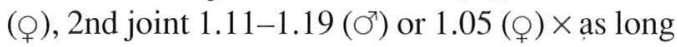
as diatone. Rostrum extending to hind coxae. Pronotum about $2.4 \times$ as broad as long in middle. Claws as in C. suturalis.

Male genitalia: Vesica in Fig. 7s.

Distribution: Saudi Arabia.

\section{C. fuscomaculata (Reuter), comb. $\mathbf{n}$.}

Figs. 5f, j, 6k-1

\section{Atomophora fuscomaculata Reuter 1879:291.}

Material studied: USSR: Buchara, 1 ex, 4.V.1911, A. Holbeck; Transcaspia, Repetek, 2 exx, 28.IV-18.V.1914, Plaviltshikov. Iran: Baluchistan, Iranshar, $800 \mathrm{~m}, 1 \mathrm{ex}$, 1-10.III.1954, Richter \& Schäuffele. Iraq: Karbala, Ukhaydir-Nukhayb, 4 exx, 2.V.1980, Linnavuori. Saudi Arabia: Yabrin, 2 exx, 16-17.III.1978, Linnavuori, in coll. Linnavuori.

Diagnosis: Subopaque. Whitish yellow. Pronotum usually with two fuscous longitudinal bands. Scutellum with X-shaped dark figure. Elytra with large fuscous spots. Legs immaculate.

Length 3.75-4.25 mm. Subopaque. Whitish or yellowish ochraceous. Frons with faint orangish lateral arcs, eyes brown. Antennae pale yellow. Pronotum usually with two longitudinal fuscous bands extending from callal area to hind margin, calli fulvous with orange dots, posterior part of disk with sparse faint orangish dotting. Scutellum with $\mathrm{X}$-shaped median figure and basal angles fuscous, pale areas of disk with a few orange dots.
Elytra: clavus, corium and cuneus with orange or partially (on clavus and along claval suture on corium) fuscous dots, and with conspicuous fuscous spots, one in apical part of clavus, one in middle of basal part of corium and two \pm fused spots on apicalmargin of corium; membrane pale brownish with darker and paler areas as seen in Fig. 5f. Legs pale yellow, apices of hind femora with orangish tinge, tibiae immaculate.

Body large and robust. Head short and broad as in $C$. astarte, eyes in $\sigma^{7}$ large, ocular index

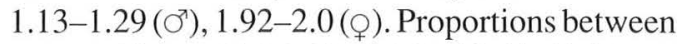

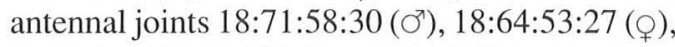
2nd joint 1.34-1.40 $\left(0^{7}\right)$ or 1.10-1.21 (ф) $\times$ as long as diatone.

Male genitalia: Vesica in Fig. 6k-1.

Biology: On Haloxylon persicum.

Distribution: Irano-Turanian.

\section{C. vitticollis (Reuter), comb. $\mathrm{n}$.}

Figs. $5 \mathrm{~g}, \mathrm{k}-1,6 \mathrm{~m}$

Atomophora vitticollis Reuter 1901:177.

Type studied: USSR, Turcmenia, male holotype, J. Sahlberg, in Mus. Helsinki.

Diagnosis: Easily recognized by blackish markings on femora and distinct dark dots on tibiae.

Length $3.75 \mathrm{~mm}$. Whitish. Short lateral arcs on frons and dots on vertex red. Eyes brown. Pronotum with two longitudinal dark brown bands extending from callal area to near hind margin, calli in front of apices of dark bands reddish brown with fuscous mottling, middle of callal area with minute red dots; disk with brown dotting. Basal angles of scutellum with dark brown spot, disk with brownish dots. Elytra: clavus and corium with brownish dots, a longitudinal spot on clavus and an inverted $\mathrm{T}$-shaped spot in medioapical angle of corium dark fuscous, cuneus pale with indistinct reddish dots; membrane whitish yaline with faint brownish mottling. Legs whitish ochraceous; under surfaces of femora with abundant blackish markings, tibiae with distinct dark dots.

Body elongate. Eyes small, ocular index 1.75. Antennae missing in the specimen studied. Claws (Fig. 6m) with broad pulvilli.

Distribution: Turcmenia. 


\section{Genus Taeniophorus Linnavuori}

Taeniophorus Linnavuori 1952:36-37. Type species: T. hyalinus Linnavuori.

Diagnosis: Like Camptotylidea, but dark dotting on upper surface usually absent. Head in lateral view longer than high. Hind tarsus short and incrassate, apex of 2nd joint bluntly oblique. Pulvilli very broad, extending to near apex of claw.

Color whitish yellow, probably greenish in life. Elytra uniformly pale or with faint fuscous dots; membrane uniformly whitish hyaline. Antennae and legs pale, immaculate.

Body small, parallel-sided. Hair covering on upper surface short, pale. Head in apical view broader than high, lower part triangular in outline, head in lateral view distinctly longer than high, frons evenly sloping apicad joining without notch on to the prominent tylus, antennal pits near lower margins of eyes. Antennae in $\sigma^{7}$ shortish and incrassate, in $o$ longish and gracile. Rostrum short, extending beyond fore coxae. Lateral margins of pronotum insinuated, calli small, distinctly elevated. Elytra longer than abdomen. Legs: tibial spines delicate, pale; hind tarsus short, about $0.25 \times$ as long as tibia (in Camptotylidea astarte $0.36 \times)$, and incrassate, apex of 2 nd joint bluntly oblique; claws gracile, pulvilli extending to near apex of claw, very broad, apex broadly rounded.

Male genitalia: Left style with coarsely dentate spine on sensory lobe. Vesica and other genitalia as in the related genera.

Distribution: Turkestan.

\section{T. hyalinus Linnavuori}

Figs. $6 \mathrm{~m}-\mathrm{s}, 7 \mathrm{v}-0 \ddot{0}, 8 \mathrm{j}-\mathrm{k}$.

Taeniophorus hyalinus Linnavuori 1952:37.

Type studied: Turkmenia, female allotype, J. Sahlberg, in coll. Linnavuori.

Material studied: USSR: Turkmenskaja SSR, AhčaKuima, 4 exx, 7.V.1974, Puchkov, in coll. Linnavuori.

Diagnosis: Characters indicated in the description of the genus.

Length $3.0-3.25 \mathrm{~mm}$. Head $0.7 \times$ as broad as basal width of pronotum. Ocular index 1.53-1.58 $\left(\sigma^{7}\right), 2.1$ (o). Proportions between antennal joints
13:46:25:20 $\left(0^{7}\right), 11: 43: 25: 23(\mathrm{Q})$, 2nd joint 1.07

$\left(\sigma^{7}\right)$ or $1.1(\odot) \times$ as long as diatone, $0.75\left(\sigma^{7}\right)$ or 0.78

$(\bigcirc) \times$ as long as basal width of pronotum.

Male genitalia in Fig. 7v-ö.

Biology: On Eremosparton flaccidum (Puchkov 1975:947).

Distribution: Turkestan.

Acknowledgements. I am greatly indebted to Dr. A. Jansson and Prof. H. Strümpel for allowing me to examine type material preserved in the Helsinki and Hamburg Museums, and to Prof. V. G. Puchkov, of Kiev, for providing interesting specimens of deserticolous Miridae from Central Asia.

\section{References}

Linnavuori, R. E. 1952: On some palearctic Hemiptera. Ann. Entomol. Fennici 18:35-41.

- 1962: A new Atomophora species from Saudi Arabia. - Ann. Entomol. Fennici 28:69-70.

- 1971: On the genus Atomophora Rt. (Het. Miridae). Stuttgart. Beitr. Naturkunde 229:1-9.

- 1984: New species of Hemiptera Heteroptera from Iraq and the adjacent countries. - Acta Entomol. Fennica 44:1-59.

- 1986: Heteroptera of Saudi Arabia. - Fauna of Saudi Arabia 8:31-197.

- 1989: New species of the Miridae and Lygaeidae (Heteroptera) from the Middle East. - Ann. Entomol. Fennici 55:49-56.

Poppius, B. 1909: Eine neue Atomophora-Art aus Sahara (Hem. Capsidae). - Ann. Entomol. Belg. 53:234.

Puchkov, V. G. 1975: On ecology and distribution of certain little-known species of Heteroptera in the Turkmenian SSR. - Dopovidi Akad. Nauk Ukr. SSR. (B) 1975(10):946-950 (in Russian, English summary).

- 1976: New species of the genus Atomophora Reuter (Heteroptera, Miridae) inhabiting Haloxylon ssp. in the Turkmen SSR. - Dopovidi Akad. Nauk Ukr. SSR. Ser. (B) 1976(7):653-656 (in Russian, English summary).

Reuter, O. M. 1879: Hemiptera Gymnocerata Europae. Hémiptères Gymnocerates d'Europa, du bassin de la Méditerranée et l'Asie Russe. II. - Preprint from: Acta Soc. Sci. Fenn. 1885:193-312.

- 1901: Capsidae rossicae descriptae. - Öfv. Finska Vet. Soc. Förhandl. 43:195-213.

- 1902: Capsidae novae mediterraneae IV. — Öfv. Finska Vet. Soc. Förhandl. 44:51-70.

- 1904: Capsidae novae Rossicae II. - Öfv. Finska Vet. Soc. Förhandl. 46:1-17.

Wagner, E. 1957: Heteropteren aus Iran 1954. II. Hemiptera-Heteroptera (Fam. Miridae) (Ergebnisse der Entomologischen Reisen Willi Richter, Stuttgart im 
Iran 1954 und 1956- Nr. 9). - Jh. Ver. vaterl. Naturk. Württemberg 112(1):74-103.

- 1965: In: Eckerlein, H. \& Wagner, E.: Ein Beitrag zur Heteropteren fauna Algeriens. - Acta Faun. Entomol. Mus. Nat. Pragae 11(104):195-243.

- 1973: Die Miriden Hahn, 1831, des Mittelmeerraumes und der Makaronesischen Inseln (Hemiptera, Heteroptera). —Entomol. Abhandl. Staatl. Mus. Tierkunde Dresden 39, Supplement, 421 pp.
- 1974: Vier neue Phylinae aus dem südlichen Algerien. — Nachrichtenblatt Bayer. Entomol. 23(1):1-11.

- 1975: Die Miridae Hahn, 1831, les Mittelmeerraumes und der Makaronesischen Inseln (Hemiptera, Heteroptera) Teil 3. - Entomol. Abhandl. Staatl. Mus. Tierkunde Dresden 40, Supplement, 483 pp.

Received 4.V.1989 